\title{
Genetic Association of Angiotensin Converting Enzyme I/D Gene Polymorphisms with Breast Cancer
}

\author{
Annum Ishfaq, Ejaz Ali, Warda Fatima and Nageen Hussain
}

\section{ABSTRACT}

\begin{abstract}
Breast cancer presents a serious public health risk in both developed and developing countries. The $A C E$ gene, which is located in chromosome $17 q 23$, has many polymorphisms. The most commonly studied is a $287 \mathrm{bp}$ Alu insertion/deletion (I/D) polymorphism in intron 16 that accounts for $50 \%$ of the variability in circulating ACE levels. The main aim of this study is to find out the association of ACE gene with breast cancer in Pakistani population. Experimental and cross-sectional. A total of 186 samples were collected. Of the 186, 93 were taken as healthy controls and 93 were the female patients suffering from breast cancer. First DNA was isolated and then further genotypes II, ID and DD were identified by Nested PCR. Chisquare $(\chi 2)$ test was applied to check the association level between ACE I/D polymorphism and breast cancer. The DD genotype showed (76) $81.7 \%$ and ID showed (17) $18.2 \%$ whereas II was not found (0) $0 \%$ in breast cancer patients. In controls, the frequency of DD is (80) $86 \%$, ID (13) $13.9 \%$ and (0) 0 percent for II genotype. It is concluded that there is no significant association of ACE I/D polymorphisms with the breast cancer $(p<0.05)$ in Pakistani population.
\end{abstract}

Keywords: Breast cancer, angiotensin converting enzyme, polymorphisms, insertion, deletion.
Published Online: July 16, 2020

ISSN: $2684-5199$

DOI :10.24018/ejbio.2020.1.4.41

\section{Annum Ishfaq}

University of the Punjab, Lahore, Pakistan.

Ejaz Ali

University of the Punjab, Lahore,

Pakistan.

(e-mail: ejaz06@gmail.com)

Warda Fatima

University of the Punjab, Lahore,

Pakistan.

(e-mail: warda.mmg@ pu.edu.pk)

Nageen Hussain*

University of the Punjab, Lahore,

Pakistan.

(e-mail: nageen.mmg@ ${ }^{\circledR}$ pu.edu.pk)

*Corresponding Author

\section{INTRODUCTION}

Breast cancer presents a serious public health risk in both developed and developing countries. With one million new cases diagnosed in the world annually, it accounts for $18 \%$ of all female malignancies [1-2]. Risk factors for this disease vary from lifestyle to genetic factors [3], which are estimated to account for $15 \%$ to $25 \%$ of the cases. Germ line mutations in high-penetrance genes, such as BRCA 1 and BRCA 2, explain $<5 \%$ of all breast cancer cases [4]. Most likely, the genetic susceptibility to breast cancer is explained by multiple highly penetrant mutations and a larger number of low penetrance mutations [5]. The genes involved in breast cancer are expected to be responsible for key processes in cell growth regulation and cell proliferation, including angiogenesis [6]. One of the newly studied angiogenic and growth factors is angiotensin II [7], which has a wide spectrum of target tissues, including breast epithelial cells. It has a variety of functions, acting as a growth factor both in normal and cancer epithelial breast cells and promoting angiogenesis [8]. Angiotensin II is converted from angiotensin I by the angiotensin-converting enzyme (ACE). Studies conducted to assess the role of ACE and ACE inhibitors in both breast cancer and cancer in general show contradicting results. Whereas ACE inhibitors have been shown to block the processes of angiogenesis and tumor growth both in vivo and in vitro [9-10], findings on the protective effect of ACE inhibitors on cancer still remain inconsistent. Whereas Lever et al. [11] found a decreased risk of cancer in patients taking ACE inhibitors, Li et al. and Friis et al. showed no protective effect of these drugs. An alternative way to study the role of ACE in cancer is to study the gene encoding for this enzyme [12]-[13]. The ACE gene, which is located in chromosome 17q23, has many polymorphisms. The most commonly studied is a $287 \mathrm{bp} \mathrm{Alu}$ insertion/deletion (I/D) polymorphism in intron 16 that accounts for $50 \%$ of the variability in circulating ACE levels [14] and has been shown to be in complete linkage disequilibrium with the putative ACE-linked quantitative trait locus in Caucasians [15-16]. Furthermore, Koh et al. showed that Chinese women who carried $I$ allele of the ACE I/D polymorphism had lower risk of developing breast cancer [17]. In this study, association of the I/D polymorphism in the $A C E$ gene to breast cancer risk in a population-based study was evaluated.

\section{METHODS}

This study is done to find out the association of ACE I/D polymorphism with breast cancer. For this purpose, blood samples were collected from INMOL Hospital and Service Hospital, Lahore-Pakistan. An informed consent was signed 
and questionnaire was filled by the patients to get the detailed information from them. A total of 186 samples were collected; of the 186, 93 were taken as controls and 93 were the patients. Inclusion and exclusion criteria were set during the collection of samples. The individuals who did not have any other disease except breast cancer were included as control. Pregnant females and those who have breast cancer along with other diseases were excluded from the study.

After the collection of samples, the next step is the extraction of DNA. After the extraction of high yield DNA, the samples were subjected to Nested PCR. It is a modified form of PCR in which three primers were used to amplify and get the bands of interest. This amplifying of DNA depends upon the temperature at which the primers anneal to the sequence of DNA and in turn the annealing temperature depends on the temperature at which the primers melt. The primers used for amplification were

\section{ACE11DF (5'CCCATCCTTTCTCCCATTTCTC3') \\ ACEID (5' GGTTTCACCGTTTTAGCCGGGA 3') \\ ACE1/DR (5' CCATGCCCATAACAGGTCTTCA 3')}

In order to check the association between ACEI/D polymorphism and risk of breast cancer, Chi-square $\left(\chi^{2}\right)$ test was done to check the association level between ACE I/D polymorphism and breast cancer via GraphPad prism software ver. 10 .

\section{RESULTS}

A total 186 individuals were enrolled in the present study, of which 93 were the patients suffering from breast cancer and 93 were the healthy controls. The effect of different parameters was checked between patients and healthy individuals to find out the biological association. Family history, marital status, menopause status and age of menarche were the parameters to be checked. Of the 93 patients, 22 had a positive family history and 71 were with negative family history whereas in case of controls 93 had a negative family history. A strong association was observed between them with the significance level at $\mathrm{p}$ value 0.0001 . Marital status of individuals was also checked. In case of patients of the 93, 89 females were married and 4 were unmarried while in controls 83 were married and 10 were singles. A significant association was not found with this parameter at $p$ value $>0.05$. The third and last factor checked was menopausal status. In case of controls, 44 females were premenopausal and 49 were post-menopausal. In case of patients, 34 were premenopausal and 59 were post-menopausal. The comparison between them showed no significant association level at $\mathrm{p}$ value greater than 0.05 as shown in Table I.

TABLE I: EFFECT OF DIFFERENT PARAMETERS WITH CONTROL AND MALIGNANT

\begin{tabular}{|c|c|c|c|c|}
\hline \multirow{2}{*}{ Parameters } & & $\begin{array}{c}\text { Control } \\
(\mathbf{n = 9 3})\end{array}$ & $\begin{array}{c}\text { Malignant } \\
(\mathbf{n = 9 3 )}\end{array}$ & \multirow{2}{*}{ P-value } \\
\hline \multirow{2}{*}{ Family history } & Positive & 0 & 22 & \multirow{2}{*}{$<0.001^{*}$} \\
\cline { 2 - 4 } & Negative & 93 & 71 & \multirow{2}{*}{0.09} \\
\hline \multirow{2}{*}{ Marital status } & Married & 83 & 89 & \multirow{2}{*}{0.13} \\
\cline { 2 - 4 } $\begin{array}{c}\text { Menopause } \\
\text { status }\end{array}$ & Unmarried & 10 & 4 & 59 \\
\cline { 2 - 4 } & Post menopause & 49 & 34 & \\
\hline
\end{tabular}

Genotype II, ID and DD were identified by nested PCR. The DD genotype showed (76) $81.7 \%$ and ID showed (17) $18.2 \%$ whereas II was not found (0) $0 \%$ in patients. In controls, the frequency of DD is (80) $86 \%$, ID (13) $13.9 \%$ and (0) 0 percent for II genotype (Fig. 1). Chi-square test gives no significant association between them that showed ACE I/D polymorphism was not associated with risk of breast cancer as shown in Table II. Breast cancer patients were categorized into two categories on the basis of menopausal status. The 59 $(63 \%)$ females showed postmenopausal status and 34 (36\%) females showed premenopausal status. The results were observed on the basis of these two categories. The female with postmenopausal status showed that frequency of ID was $12(20 \%)$ and DD was $47(79.6 \%)$ while female with premenopausal status showed frequency of ID was $5(14.7 \%)$ and DD was of 29 (85\%) (Fig. 2). A significant association was not analyzed through chi square test as shown in Table III.

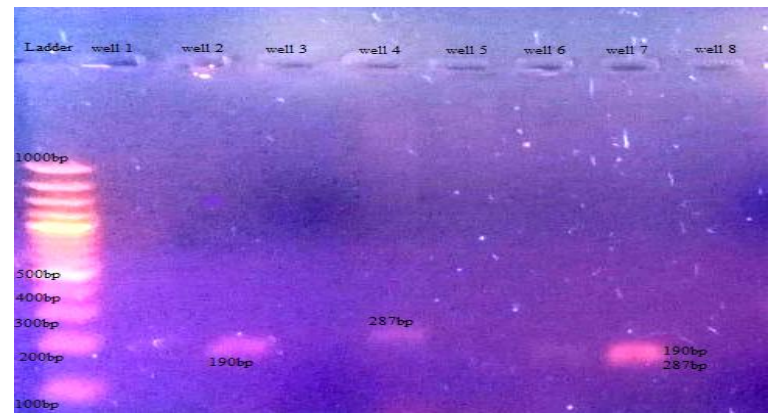

Fig.1. ACE genotype in breast cancer patients (190bp: DD, 287:II, 198bp+287bp: ID).

TABLE II: AsSOCIATION OF ACEI/D POLYMORPHISM WiTH BREAST

\begin{tabular}{|c|c|c|c|c|}
\hline Genotype & Malignant & Control & $\begin{array}{c}\text { Chi-square } \\
\text { test }\end{array}$ & p-value \\
\hline II & 0 & 0 & & \multirow{2}{*}{0.635} \\
\hline ID & 17 & 13 & 0.425 \\
\hline DD & 76 & 80 & & \\
\hline
\end{tabular}

TABLE III: AsSOCIATION OF MENOPAUSE STATUS With Risk OF DEVELOPING DISEASE

\begin{tabular}{|c|c|c|c|c|c|c|}
\hline & & II & ID & DD & $\begin{array}{c}\text { Chi- } \\
\text { square }\end{array}$ & $\begin{array}{c}\text { p- } \\
\text { value }\end{array}$ \\
\hline \multirow{2}{*}{$\begin{array}{c}\text { Menopausal } \\
\text { status }\end{array}$} & $\begin{array}{c}\text { Post } \\
\text { menopause }\end{array}$ & 0 & 12 & 47 & & \\
\cline { 2 - 5 } & $\begin{array}{c}\text { Pre } \\
\text { menopause }\end{array}$ & 0 & 5 & 29 & 0.458 & 0.49 \\
\hline
\end{tabular}

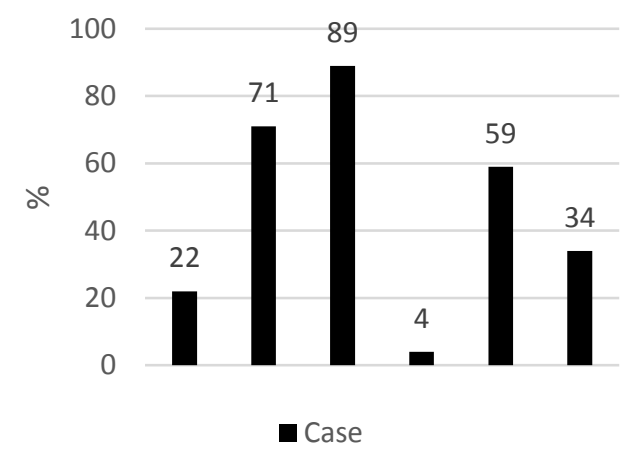

Fig.2. Comparison of different parameters in Breast cancer patients $(n=93)$ 


\section{DISCUSSION}

In developed and developing countries, breast cancer is a health risk disease that is rapidly spreading in all over the entire world. Annually, its risk increases to 18 percent and 1 million cases were reported. Different environmental risk factors were included in developing the disease and some genetic factors were also at the top [18]. Genetic factor included the mutation in the breast cancer genes that developed the cancers, gene includes BRCA genes [19]. These genes normally responsible for the cell proliferation at a normal extent including angiogenesis [20]. A growth factor that is studied recently is angiotensin II that triggers the cells of breast epithelial [21]. Angiotensin II is generated with the help of ACE into angiotensin I. Studies illustrating that I/D polymorphism is a blood pressure marker and involved in increasing myocardial risk. The present study is conducted to evaluate the association of breast cancer with ACEI/D polymorphism. For this purpose, 1:1 was maintained in case control study. Different factors were including in study that were family history, marital status and menopausal status as shown in Fig. 1. A significant association was observed with the family history of control and patients at $p$ value less than 0.05 .

A study reported in UTAH population in which family history impact was checked in breast cancer patients and reported that three-fold risk of breast cancer was increased in patients having positive family history [22]. A study reported that menopause status has a strong association with the breast cancer. In the present study, the impact of marital status was checked and concluded that there is no effect of marital status on the risk of developing malignant tumor as $p$ value greater than 0.05 . A study made on Iran population revealed a strong association of marital status and history of family with risk of breast cancer [23]. Another factor contributing to breast cancer was menopause status. It has been observed that there is no association between the premenopausal status and postmenopausal status as the $\mathrm{p}$ value $>0.05$.

According to the study made on different populations, it has been reported that there is no significant association between I/D polymorphism in ACE gene and breast cancer risk [24]. Another study made on Caucasian women revealed that ACEI/D polymorphism has a key role in developing risk of breast cancer. In this study DD genotype was responsible for increasing the breast cancer risk [25]. It has been concluded in present research that there is no remarkable association between the ACEI/D gene and breast cancer. The ID genotype was 17 in malignant patients and 13 were in control healthy individuals whereas the genotype DD was 76 in breast cancer patients and 80 was in normal healthy individuals. The association was checked through chi-square and revealed that there is no significant association between the ACE I/D gene and Breast cancer risk as $\mathrm{p}$ value $>0.05$. Thus, the results suggested that ACE I/D polymorphism may not play a key role in developing the risk of breast cancer.

\section{ACKNOWLEDGMENT}

I would like to acknowledge the staff of different hospitals for their inclusive guidance and help during this research work. I would like to acknowledge the breast cancer patients without whom the study was not possible.

\section{REFERENCES}

[1] Perera NM, Gui GP, "Multi-ethnic differences in breast cancer: current concepts and future directions". Int J Cancer, vol. 106, pp. 463-7, 2003.

[2] Prichard RS, Hill AD, Dijkstra B, "The prevention of breast cancer." Br J Surg, vol. 90, pp. 772-83, 2003.

[3] Singletary SE, "Rating the risk factors for breast cancer." Ann Surg, vol. 23, pp. 474-82, 2002.

[4] Mitrunen K, Hirvonen A, "Molecular epidemiology of sporadic breast cancer: The role of polymorphic genes involved in oestrogen biosynthesis and metabolism." Mutat Res, vol. 554, pp. 39-41, 2003.

[5] Nathanson KL, Wooster R, Weber BL, "Breast cancer genetics: what we know and what we need." Nat Med, vol. 7, pp. 552-6, 2001.

[6] Folkman J, Shing Y, Angiogenesis. J Biol Chem, vol. 267, pp. 109314, 1992.

[7] Walther T, Menrad A, Orzechowski HD, "Differential regulation of in vivo angiogenesis by angiotensin II receptors." FASEB J, vol. 17, pp. 2061-7, 2003.

[8] Greco S, Muscella A, Elia MG, "Activation of angiotensin II type I receptor promotes protein kinase $\mathrm{C}$ translocation and cell proliferation in human cultured breast epithelial cells." J Endocrino, vol. 174, pp. 205-14, 2002.

[9] Fujita M, Hayashi I, Yamashina S, "Blockade of angiotensin AT1a receptor signaling reduces tumor growth, angiogenesis, and metastasis." Biochem Biophys Res Commun, vol. 294, pp. 441-7, 2003.

[10] Volpert OV, Ward WF, Lingen MW," Captopril inhibits angiogenesis and slows the growth of experimental tumors in rats." $J$ Clin Invest, vol. 98, pp.671-9, 1996

[11] Lever AF, Hole DJ, Gillis CR, "Do inhibitors of angiotensin-Iconverting enzyme protect against risk of cancer?" Lancet, vol. 352 pp. 179-84, 1998

[12] Li CI, Malone KE, Weiss NS, "Relation between use of antihypertensive medications and risk of breast carcinoma among women ages 65-79 years." Cancer, vol. 98, pp. 1504-13, 2003.

[13] Friis S, Sorensen HT, Mellemkjaer L, "Angiotensin-converting enzyme inhibitors and the risk of cancer: a population-based cohort study in Denmark." Cancer, vol. 92, pp. 2462-70, 2001.

[14] Tiret L, Rigat B, Visvikis S, "Evidence from combined segregation and linkage analysis, that a variant of the angiotensin I-converting enzyme (ACE) gene controls plasma ACE levels." Am J Hum Genet, vol. 51, pp. 197-205, 1992

[15] Keavney B, McKenzie CA, Connell JM, "Measured haplotype analysis of the angiotensin-I converting enzyme gene." Hum Mol Genet, vol. 7, pp. $1745-51,1998$

[16] McKenzie CA, Abecasis GR, Keavney B, "Trans-ethnic fine mapping of a quantitative trait locus for circulating angiotensin I-converting enzyme (ACE)." Hum Mol Genet, vol. 10, pp. 1077-8, 2001.

[17] Koh WP, Yuan JM, Sun CL, "Angiotensin I-converting enzyme (ACE) gene polymorphism and breast cancer risk among Chinese women in Singapore." Cancer Res, vol. 63, pp. 573-8, 2003.

[18] Ebrahimi, M., Vahdaninia, M. and Montazeri, A. "Risk factors for breast cancer in Iran: a case-control study." Breast cancer research, vol. 4, pp. 463-7, 2002.

[19] Hanahan, D. and Folkman, J, "Patterns and emerging mechanisms of the angiogenic switch during tumorigenesis." Cell, vol. 86, pp. 353-64, 1996.

[20] Ladd, A. M. G.-Z., Vásquez, A. A., Sayed-Tabatabaei, F. A., Coebergh, J. W., Hofman, A., Njajou, O., Stricker, B. and van Duijn, C. "Angiotensin-converting enzyme gene insertion/deletion polymorphism and breast cancer risk." Cancer Epidemiology and Prevention Biomarkers, vol. 14, pp. 2143-46, 2005.

[21] Mitrunen, K. and Hirvonen, A, "Molecular epidemiology of sporadic breast cancer: the role of polymorphic genes involved in oestrogen biosynthesis and metabolism." Research/Reviews in Mutation Research, vol. 544, pp. 9-41, 2003

[22] Pei, X.-H. and Li, H.-X, "Insertion/deletion (I/D) in the angiotensinconverting enzyme gene and breast cancer risk: lack of association in a meta-analysis." Asian Pacific Journal of Cancer Prevention, vol. 13, pp. 5633-36, 2012.

[23] Schmidt, S., Grobbee, D., Ganten, D. and Ritz, E, "Polymorphism of the angiotensin I converting enzyme gene is apparently not related to high blood pressure: Dutch Hypertension and Offspring Study." Journal of hypertension, vol. 11, pp. 345-48, 1993. 1993;11:345-348. 
[24] Slattery, M. L. and Kerber, R. A, "Family history of cancer and colon cancer risk: the Utah Population Database. JNCI:" Journal of the National Cancer Institute vol.86, pp. 1618-1626, 1994.

[25] Trentham-Dietz, A., Sprague, B. L., Hampton, J. M., Miglioretti, D. L., Nelson, H. D., Titus, L. J., Egan, K. M., Remington, P. L. and Newcomb, P. A. "Modification of breast cancer risk according to age and menopausal status: a combined analysis of five population-based case-control studies." Breast cancer research and treatment, vol. 145 , pp. $165-175,2014$

[26] Walther, T., Menrad, A., Orzechowski, H.D., Siemeister, G., Paul, M and Schirner, M. "Differential regulation of in vivo angiogenesis by angiotensin II receptors." The FASEB Journal, vol. 17, pp. 2061-67, 2003.

ANNUM ISHFAQ did her M.Phil in Microbiology and Molecular Genetics from University of the Punjab. She worked on Breast cancer project funded by University of the Punjab. In the present article, she did an experimental work.

EJAZ ALI can work in a challenging environment where he can fully utilize his knowledge, skills, efficiency and responsibility in facilitating the growth of the organization and to grow personal research abilities. He did his M.Phil in Microbiology and Molecular Genetics from University of the Punjab. He worked on two projects; one was, Association of GJB2 Gene with hearing loss in population of Gilgit-Baltistan, Pakistan funded by University of the Punjab, Lahore and Higher Education Commission, Pakistan. Second project was Effect of salinity on medicinal plants of Gilgit-Baltistan, Pakistan funded by University of Karachi. In the present article he did an experimental work.

DR. WARDA FATIMA is working as an Assistant professor in the department of Microbiology and Molecular Genetics, University of the Punjab. She has a teaching and research experience of more than 5 years. She has 5 publications. Her field of specialization is Molecular Genetics. In the present article she was the co-principal investigator.

DR. NAGEEN HUSSAIN is working as an Assistant professor in the department of Microbiology and Molecular Genetics, University of the Punjab since 2005. She has a teaching and research experience of more than 15 years. She has more than 25 publications. Her field of specialization is Immunogenetics. She has worked on number of projects funded by different organizations. She has presented her research work internationally in Japan, Amsterdam, Switzerland, USA, Dubai, Bangkok. In the present article, she was the Principal Investigator and the corresponding author. 